\title{
Study of Undescended Testes by High Frequency Ultrasound
}

\author{
Estudio por Ultrasonido de Alta Frecuencia de los Testículos no Descendidos
}

\author{
"Deepali Onkar; "**Prashant Onkar \& **Kajal Mitra
}

ONKAR, D.; ONKAR, P. \& MITRA, K. Study of undescended testes by high frequency ultrasound. Int. J. Morphol., 30(3):10851089, 2012.

SUMMARY: Undescended testes or cryptorchidism in the most common congenital anomaly of male reproductive system. The descent is multifactorial with gubernaculums playing major role. The failure of descent can be at trans-abdominal or inguino-scrotal phase. Locating undescended testes is important in view of low fertility and high rate of occurrence of neoplasm in them. Ultrasound is the standard imaging technique of choice in children with a non-palpable testis as it is non-invasive and does not use ionizing radiation. Position of testis is also important in deciding whether patient will need abdominal or inguinal exploration. The aim was to study the position of undescended testes by high frequency ultrasound and its embryonic explanation. Total 41 boys with undescended testes underwent high frequency ultrasound. The location of testis was noted followed by its size and echotexture. Thirty patients had unilateral and 11 had bilateral undescended testes. The prevalence was more on right side (16 out of 30). Out of total 52, 46 (88\%) testis were located by ultrasound. Six (12\%) testes could not be located. Five (10\%) were retractile testes. Out of remaining 41, $26(63 \%)$ were located in inguinal canal and 15 (37\%) were located in abdomen. Out of 15 abdominal testes 9 were located just proximal to inguinal canal and 6 were located in deep pelvis. High frequency ultrasound was able to locate the position of undescended testes in majority $(88 \%)$ of the cases.

KEY WORDS: Cryptorchidism; Ultrasound; Inguinal canal; Non-palpable testes.

\section{INTRODUCTION}

Undescended testis is the commonest congenital anomaly of male reproductive system and in view of low fertility and high rate of occurrence of neoplasm locating them at the earliest is important. Incidence is around 0.8$2 \%$ in full term new born and around $18-30 \%$ in premature births. It is unilateral in $18-30 \%$ of cases. $20 \%$ of them are reported non-palpable (Güvenç et al., 2005).

The descent of testes into inguinal canal is multifactorial with gubernaculum playing major role.

The mechanism of testicular descent is not completely understood and to some extent remains controversial. Recent evidence suggest that it involves two phases, Tran abdominal and inguinoscrotal, that are regulated by distinct morphological and endocrine factors (Stradring, 2008).

In the intra abdominal stage Leydig cells secrete a factor called insulin like growth factor three (Insl 3) which targets on G-proten coupled receptor referred to as LGR8. Mutation in this LRG8 has been identified in case of human cryptorchidism.
In the absence of testosterone generated by Leydig cells or in the case of non functional or absent androgen receptors, testicular descent is arrested at inguino scrotal stage (Schoenwolf et al., 2009). Beasley \& Hutson (1988) found that ddistal transection of gubernaculum resulted in failure of descent in 27 rats. Park \& Hutson (1991) demonstrated that gubernaculum is highly motile during testicular descent.

Non descent requires early detection as spontaneous descent is rare beyond 6 months after birth. Surgical treatment like orchidopexy around $9 \mathrm{~m}$ has beneficial effect on growth of previously undescended testes (Kollin et al., 2006). Also risk of testicular neoplasm in abdominal testes is reported to be more.

Graif et al. (1990) studied 45 cases of undescended testes by high-resolution ultrasound. 36 (97\%) out of 37 palpable testes and $6(75 \%)$ out of 8 impalpable testes were correctly localized by ultrasound which modified the consequent surgical approach. 
With the purpose of studying the position of undescended testes by high frequency ultrasound and its embryonic explanation this study was undertaken.

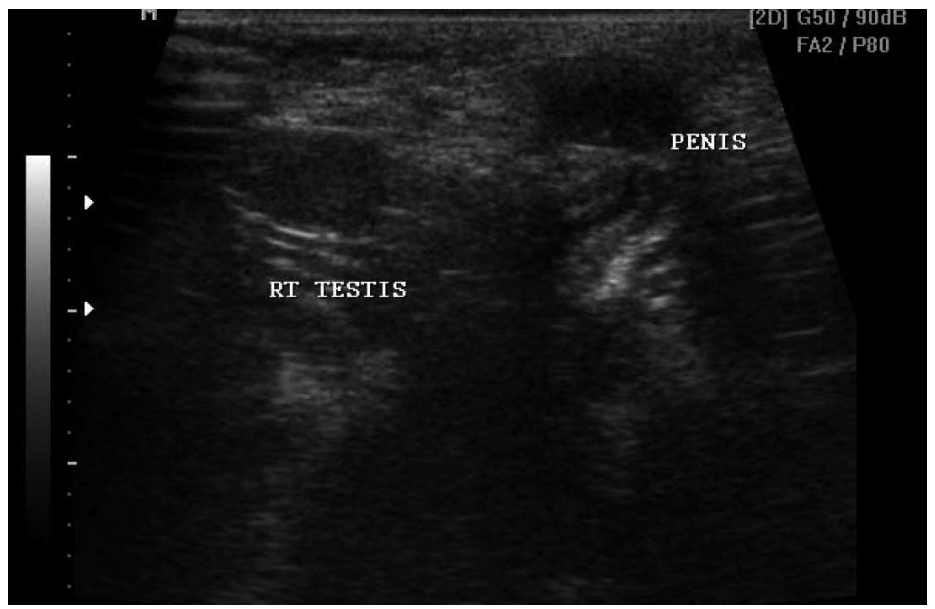

Fig. 1. Inguinal testis.

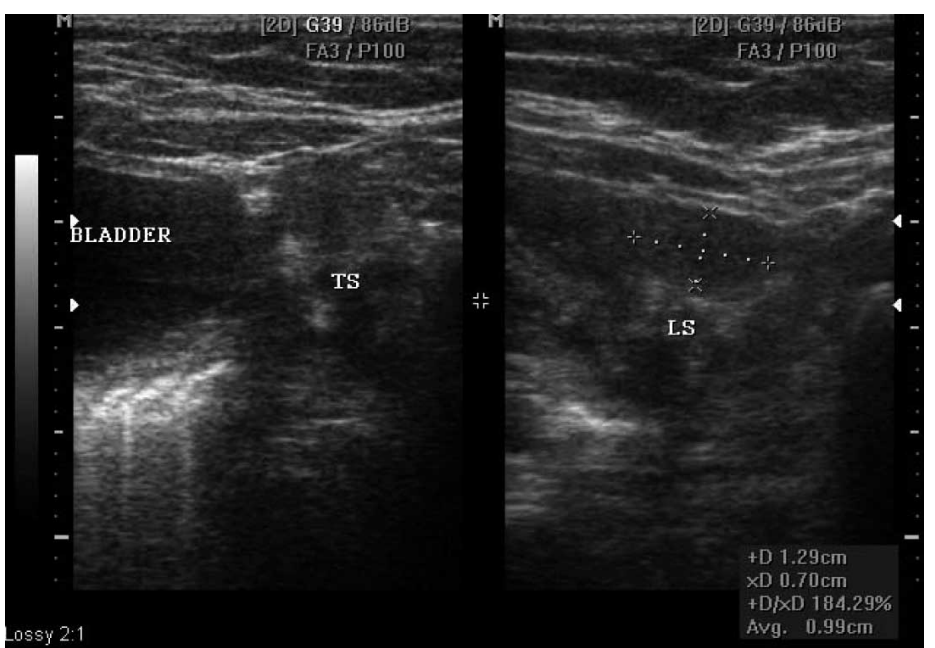

Fig. 2. Abdominal testis.

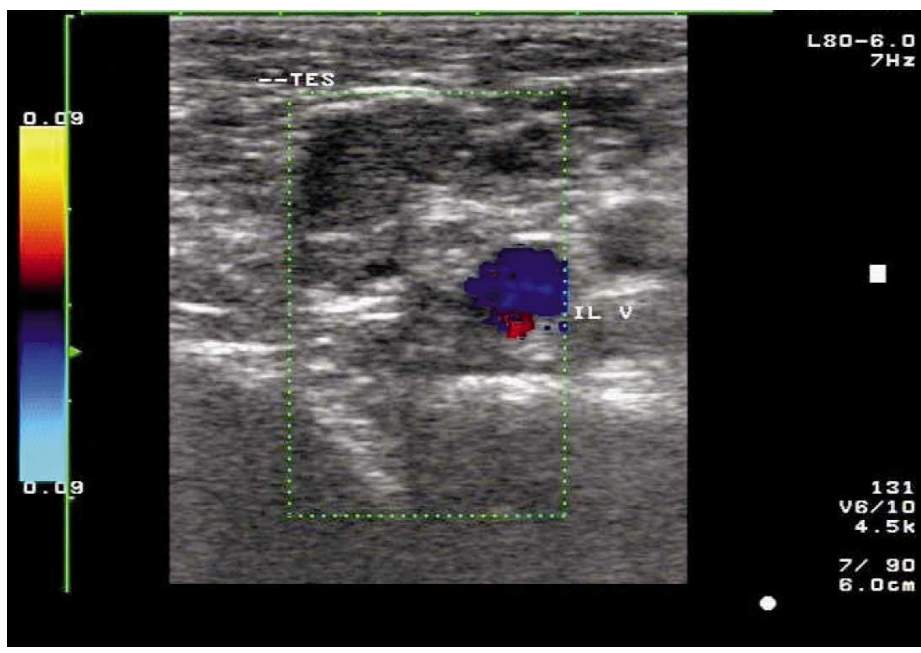

Fig. 3. Abdominal testis near external iliac vein.

\section{MATERIAL AND METHOD}

Total 41 boys referred with clinical diagnosis of undescended testes were subjected to high frequency ultrasound by linear broadband transducer of frequency 7.5-10 MHz on Toshiba Core vision and Esaote My lab 50 ultrasound machine. The examination was targeted to look for undescended testis in inguinal region and/or pelvis. The location of testis was noted followed by its size and echotexture. If necessary repeat examination was conducted.

\section{RESULTS}

Total 41 patients were studied. Patient age ranged from 4 months to 14 years. 52 non palpable testes were evaluated. Clinically 30 patients had unilateral whereas 11 had bilateral undescended testes. In unilateral cases prevalence was observed more on right side with number $16(53 \%)$ and $14(47 \%)$ on left side.

Ultrasound was able to localize position of the $46(88 \%)$ testis. $6(12 \%)$ testes could not be located. Retractile testes were found in $5(10 \%)$ cases. Out of remaining 41 testes, $26(63 \%)$ were located in inguinal canal (Fig. 1) and $15(37 \%)$ were located in abdomen. 9 of the 15 abdominal testes were located just proximal to inguinal canal and 6 were in pelvis (Figs. 2 and 3).

\section{DISCUSSION}

The term cryptorchidism is derived from the Greek words 'Kryptos 'meaning 'hidden' and 'orchis' meaning testes (Tomiyama et al., 2005).

Descent of the testis involves two different phases trans-abdominal and inguinal phase. Gubernaculum testes plays major role in descent of testes. Gubernaculum condenses during $7^{7^{\text {th }}}$ week. In the trans-abdominal phase between $7^{\text {th }}$ and $12^{\text {th }}$ week the extra inguinal portion of gubernaculum shortens and pulls the testis down to the vicinity of deep inguinal ring. In inguino-scrotal phase the testis remains in the vicinity of deep inguinal ring from $3^{\text {rd }}$ to $7^{\text {th }}$ month, but then enters the inguinal canal. By 
$9^{\text {th }}$ month just before normal term delivery the testis have completely entered the scrotal sac (Schoenwolf et al.). During the trans-abdominal phase the testis is held by the gubernaculum near the inguinal region. As the fetus enlarges insulin 3 secreted by leydig cells stimulates gubernaculum enlargement augmented by MIS (mullerian inhibiting substance) and T (testosterone) which also causes regression of cranial suspensory ligament (CSL) (Hutson \& Hasthorpe, 2005).

During inguino-scrotal phase the gubernaculum migrates and elongates towards the scrotum under androgenic action which is indirect via genitofemoral nerve (GFN) and release of calcitonin-Gene Related-peptide (CGRP). Beasley \& Hutson found that ddistal transection of gubernaculum resulted in failure of descent of testis in all 27 rats. Park \& Hutson demonstrated that gubernaculum is highly motile during testicular descent. Rhythmic contractions suggest the presence of possible smooth musclelike components that may be modulated by CGRP release from the genitofemoral nerve. Insufficient testosterone during development may result in failure to produce enough nerve cells in the genitofemoral nerve; then at the time of testicular migration too little CGRP is produced than required to stimulate contractions in the gubernaculum and assist testicular descent (Park \& Hutson). The gubernaculum gives rise to both smooth and striated muscles. The testis is descended through processes vaginalis via the propulsive force generated by the muscles. Failure of descent is associated with the diminution of smooth muscle content and decrease in sympathetic tone that depends on androgens (Tanyel, 2004).

In the inguino scrotal phase of descent, androgens and pituitary hormones clearly play essential role. In the absence of testosterone generated by Leydig cells or in the case of non functional or absent androgen receptors, testicular descent is arrested at inguino scrotal stage.

Normal testicular descent is dependent on the intact hypothalamus-pituitary axis. Malformations of CNS and congenital hypogonadotrophic hypogonadism may be associated with cryptorchidism (Virtanen et al., 2007). Other factors include increased intra-abdominal temperature and HCG from maternal circulation.

Non descent requires early detection as spontaneous descent is rare beyond 6 months and occurs only in around $7 \%$ till age of $1 \mathrm{yr}$ (Wenzler et al., 2004). Surgical treatment like orchidopexy around $9 \mathrm{~m}$ has beneficial effect on growth of previously undescended testes (Kollin et al.).

Murphy et al. (2007) studied orchidopexy and impact on fertility and recommended orchidopexy soon after 6-7 months of age, corrected for term, to maximize the future fertility potential. They also found good $(90 \%)$ fertility outcome in unilateral undescended testes and most of the bilateral abdominal testis as infertile.

Maturation of germ cells starts with differentiation of gonocytes in to spermatogonia and is usually completed by the age of 6 months. Dark A (Ad) spermatogonia start to appear and steadily increase in number. This number is reduced in testis of cryptorchid boys indicating that there is failure in the maturation process of the spermatogenic cells (Kurpisz et al., 2010).

Risk of testicular neoplasm by performing biopsy at the time of orchidopexy in abdominal testes was found to be $4 \%$ whereas no single case was found in 1281 testes descended after birth (Cortes et al., 2004). Therefore early evaluation of this anomaly is required. Ultrasound tops the list of imaging studies for obvious advantages like availability, non-invasive nature and low cost. In our study out of total 52 undescended testes $46(88 \%)$ could be located by ultrasound. Out of 46 testes located by ultrasound $5(10 \%)$ were retractile, out of remaining 41, 26 (63\%) were in inguinal canal, 15 (37\%) were located in abdomen. Luciano studied 133 cryptorchid testes and found 17 (12\%) abdominal, 92 (69\%) inguinal, 24 (18\%) high scrotal (Favorito et al., 2003). In our study out of 15 abdominal testis $9(60 \%)$ were located just proximal to inguinal ring and $6(40 \%)$ were seen in pelvic region.

Graif et al. (1990) studied 45 cases of undescended testes by high-resolution ultrasound. $36(97 \%)$ out of 37 palpable testes and $6(75 \%)$ out of 8 impalpable testes were correctly localized by ultrasound which modified the consequent surgical approach. The three testes missed by the ultrasound examination were found to be atrophic. Three intra-abdominal testes just proximal to the internal ring were identified by ultrasound preoperatively.

Nijs et al. (2007) studied 103 non-palpable testes by high frequency ultrasound and out of 87 inguinal 85 (97\%) inguinal and out of 30 abdominal testes $16(48 \%)$ were located by high frequency ultrasound. We found $5(10 \%)$ retractile testis. Retractile testis represents hyperactivity of the cremasteric reflex (Tanyel).

Bierklund et al. (1988) studied ultrasound and clinical examination in the assessment of the exact position of an undescended testicle, and to see whether ultrasound could help discern retractile and truly undescended testicles. Out of 123 undescended testicles, 47 were assessed retractile and 66 truly undescended. Ultrasound had a sensitivity, specificity and accuracy of $100 \%$ for testicles positioned distally to the internal ring. 
In our study out of 41,25 had unilateral and 8 had bilateral undescended testis. Incidence was observed more on right side. (60\%) Hyens \& Hutson (1995) found asymmetrical descent in 13 out of 78 fetuses. The left testis had descended prior to right in $9(70 \%)$ out of 13 cases. Non-descent occurred more commonly on the right in 11 $(65 \%)$ of the 17 undescended testis.

Unilateral undescended testis is more likely to occur because androgens act independently on each side via the ipsilateral genitofemoral nerve and defects in neuronal development of CGRP action could lead to unilateral undescended testis (Hutson \& Hasthorpe). Phewplung et al. (2010) found bilateral undescended testis in 19 and unilateral in 20 boys. We have done ultrasound as first and only investigation and could locate around $88 \%$ of undescended testes.

In conclusion, a high frequency ultrasound was able to locate the position of undescended testes in majority $(88 \%)$ of the cases. Undescended testes were more commonly found in inguinal canal than abdomen; finally the ultrasound findings can be useful to determine the time and also the type of surgery i.e. inguinal or abdominal exploration.

ONKAR, D.; ONKAR, P. \& MITRA, K. Estudio por ultrasonido de alta frecuencia de los testículos no descendidos . Int. J. Morphol., 30(3):1085-1089, 2012.

RESUMEN: La criptorquidia o testículos no descendidos es la anomalía congénita más común del sistema reproductivo masculino. El descenso es multifactorial, donde el gubernaculum testis juega un rol fundamental. El fracaso de descenso puede ocurrir en fase trans-abdominal o inguino-escrotal. Conocer la localización de los testículos no descendidos es importante en vista de la baja fertilidad y alta tasa de incidencia de neoplasia en ellos. La ecografía es la técnica imagenológica estándar y de elección en niños con testículos no palpables, ya que no es invasiva y no utiliza radiación ionizante. La posición del testículo también es importante para decidir si el paciente necesita exploración abdominal o inguinal. El objetivo fue estudiar la posición de los testículos no descendidos por ultrasonido de alta frecuencia y su explicación embrionaria. Un total de 41 niños con testículos no descendidos se sometieron a ultrasonido de alta frecuencia. Se estudió la ubicación, tamaño y ecotextura del testículo no descendido. Treinta pacientes presentaron el testículo no descendido de manera unilateral y 11 bilateral. La prevalencia fue mayor en el lado derecho (16 de 30). Del total de 52 de testículos, 46 (88\%) fueron localizados por ultrasonido. Seis (12\%) no pudieron ser localizados. Cinco (10\%) fueron testículos retráctiles. De los 41 testículos no descendidos, 26 (63\%) se localizaron en el canal inguinal y 15 (37\%) en el abdomen. De los 15 en posición abdominal, 9 se encontraron justo proximal al canal inguinal y 6 en la pelvis profunda. El ultrasonido de alta frecuencia fue capaz de localizar la posición de los testículos no descendidos en la mayoría (88\%) de los casos.

PALABRAS CLAVE: Criptorquidia; Ultrasonido; Canal inguinal; Testículos no palpables.

\section{REFERENCES}

Beasley, S. W. \& Hutson, J. M. The role of the gubernaculum in testicular descent. J. Urol., 140(5 Pt 2):1191-3, 1988.

Bjerklund Johansen, T. E. \& Larmo, A. Ultrasound in the evaluation of retractile and truly undescended testes. Scand. J. Urol. Nephrol., 22(4):245-50, 1988.

Cortes, D.; Thorup, J. \& Petersen, B. L. Testicular neoplasia in undescended testes of cryptorchid boys-does surgical strategy have an impact on the risk of invasive testicular neoplasia? Turk. J. Pediatr., 46 Suppl:35-42, 2004.

Favorito, L. A.; Klojda, C. A.; Costa, W. S. \& Sampaio, F. J. Is there a relationship with anomalous insertions of the distal gubernaculum testis and testicular ectopia? Analysis in human fetuses and patients with cryptorchidism. J. Urol., 170(2 Pt 1):554-7, 2003.

Graif, M.; Czerniak, A.; Avigad, I.; Strauss, S.; Wolfstein, I. \&
Itzchak, Y. High-resolution sonography of the undescended testis in childhood: an analysis of 45 cases. Isr. J. Med. Sci., 26(7):382-5, 1990.

Güvenç, B. H.; Sözübir, S.; Ekingen, G. \& Senel, U. Advantages of video-assisted approach in detecting epididymal anomalies and treatment of nonpalpable testis. Urol. Int., 74(2):127-34, 2005.

Heyns, C. F. \& Hutson, J. M. Historical review of theories on testicular descent. J. Urol., 153(3 Pt 1):754-67, 1995.

Hutson, J. M. \& Hasthorpe, S. Testicular descent and cryptorchidism: the state of the art in 2004. J. Pediatr. Surg., 40(2):297-302, 2005.

Kollin, C.; Hesser, U.; Ritzén, E. M. \& Karpe, B. Testicular growth from birth to two years of age, and the effect of orchidopexy at age nine months: a randomized, controlled study. Acta Paediatr., 95(3):318-24, 2006. 
Kurpisz, M.; Havryluk, A.; Nakonechnyj, A.; Chopyak, V. \& Kamieniczna, M. Cryptorchidism and long-term consequences. Reprod. Biol., 10(1):19-35, 2010.

Murphy, F.; Paran, T. S. \& Puri, P. Orchidopexy and its impact on fertility. Pediatr. Surg. Int., 23(7):625-32, 2007.

Nijs, S. M.; Eijsbouts, S. W.; Madern, G. C.; Leyman, P. M.; Lequin, M. H. \& Hazebroek, F. W. Nonpalpable testes: is there a relationship between ultrasonographic and operative findings? Pediatr. Radiol., 37(4):374-9, 2007.

Park, W. H. \& Hutson, J. M. The gubernaculum shows rhythmic contractility and active movement during testicular descent. J. Pediatr. Surg., 26(5):615-7, 1991.

Phewplung, T.; Mahayosnond, A. \& Trinavarat, P. Accuracy of ultrasound in pediatric undescended testes. Asian Biomed., 4(6):983-6, 2010.

Schoenwolf, G. C.; Bleyl, S. B.; Brauer, P. R. \& Francis-West, P. H. Larsen's Human Embryology. $4^{\text {th }}$ ed. New York, Churchill Livingstone, 2009. pp.26-530.

Stradring, S. Development of urogenital system. In: Gray's Anatomy, 40 ${ }^{\text {th }}$ ed. New York, Churchill Livingstone, 2008. pp.1305-26.

Tanyel, F. C. The descent of testis and reason for failed descent. Turk. J. Pediatr., 46(Suppl.):7-17, 2004.

Tomiyama, H.; Sasaki, Y.; Huynh, J.; Yong, E.; Ting, A. \& Hutson, J. M. Testicular descent, cryptorchidism and inguinal hernia: the Melbourne perspective. J. Pediatr. Urol., 1(1):11-25, 2005.

Virtanen, H. E.; Bjerknes, R.; Cortes, D.; Jorgensen, N.; RajpertDe Meyts, E.; Thorsson, A. V.; Thorup, J. \& Main, K. M. Cryptorchidism: classification, prevalence and long-term consequences. Acta Paediatr., 96(5):611-6, 2007.

Wenzler, D. L.; Bloom, D. A. \& Park, J. M. What is the rate of spontaneous testicular descent in infants with cryptorchidism? J. Urol., 171(2 Pt 1):849-51, 2004.

\author{
Correspondence to: \\ Deepali Onkar \\ Associate Professor Anatomy \\ NKP Salve Institute of Medical Sciences \\ and Research Centre \\ 175 Bajaj, Nagar \\ Nagpur, 440010 \\ INDIA \\ Phone: $+91-712-2248590$ \\ +91-9822248570
}

Email: drdeepalionkar@yahoo.com

drprashantonkar@hotmail.com

Received: 08-08-2011

Accepted: 11-01-2012 